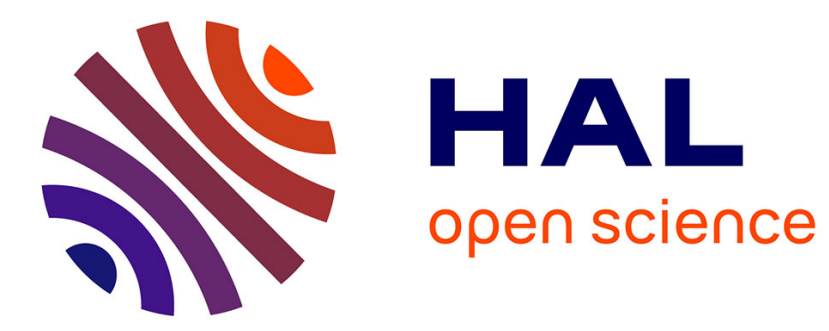

\title{
Yeast cell based feed additives: Studies on aflatoxin B1 and zearalenone
}

Sebastian Fruhauf, Heidi Schwartz, Franz Ottner, Rudolf Krska, Elisavet Vekiru

\section{- To cite this version:}

Sebastian Fruhauf, Heidi Schwartz, Franz Ottner, Rudolf Krska, Elisavet Vekiru. Yeast cell based feed additives: Studies on aflatoxin B1 and zearalenone. Food Additives and Contaminants, 2011, pp.1. 10.1080/19440049.2011.630679 . hal-00761689

\section{HAL Id: hal-00761689 \\ https://hal.science/hal-00761689}

Submitted on 6 Dec 2012

HAL is a multi-disciplinary open access archive for the deposit and dissemination of scientific research documents, whether they are published or not. The documents may come from teaching and research institutions in France or abroad, or from public or private research centers.
L'archive ouverte pluridisciplinaire HAL, est destinée au dépôt et à la diffusion de documents scientifiques de niveau recherche, publiés ou non, émanant des établissements d'enseignement et de recherche français ou étrangers, des laboratoires publics ou privés. 


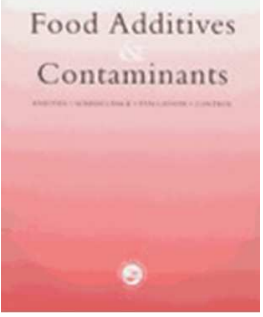

\section{Yeast cell based feed additives: Studies on aflatoxin B1 and} zearalenone

\begin{tabular}{|c|c|}
\hline Journal: & Food Additives and Contaminants \\
\hline Manuscript ID: & TFAC-2010-442.R1 \\
\hline Manuscript Type: & Original Research Paper \\
\hline Date Submitted by the Author: & 05-Sep-2011 \\
\hline Complete List of Authors: & $\begin{array}{l}\text { Fruhauf, Sebastian; University of Natural Resources and Life Sciences, } \\
\text { Vienna, IFA Tulln } \\
\text { Schwartz, Heidi; University of Natural Resources and Life Sciences, Vienna, } \\
\text { IFA Tulln } \\
\text { Ottner, Franz; University of Natural Resources and Life Sciences, Vienna, } \\
\text { Department of Civil Engineering and Natural Hazards } \\
\text { Krska, Rudolf; University of Natural Resources and Life Sciences, Vienna, } \\
\text { IFA Tulln } \\
\text { Vekiru, Elisavet; University of Natural Resources and Life Sciences, Vienna, } \\
\text { IFA Tulln }\end{array}$ \\
\hline Methods/Techniques: & Chromatography - HPLC, Chromatography - LC/MS \\
\hline Additives/Contaminants: & Aflatoxins, Mycotoxins, Mycotoxins - zearalenone \\
\hline Food Types: & Animal feed \\
\hline Abstract: & $\begin{array}{l}\text { Thirty commercially available yeast cell wall products and two reference } \\
\text { bentonites were tested for their ability to bind aflatoxin B1 (AFB1) and } \\
\text { zearalenone (ZON) in buffer solutions at pH } 3 \text { and pH } 6.5 \text { as well as in real } \\
\text { gastric juice. For most products, the binding efficacy of AFB1 correlated } \\
\text { with the ash content which was between } 2.6 \text { and } 89 \% \text { and constituted the } \\
\text { inorganic non-volatile components, like mineral clays, of the samples. } \\
\text { Samples with smectite as main ash component showed highest binding } \\
\text { efficacy. Yet, correlation with the content of mannanooligosaccharides } \\
\text { (MOS) and beta-glucanes from yeast cell walls was not observed. Products } \\
\text { containing }>30 \% \text { ash showed AFB1 adsorption values }>90 \% \text { at least in } \\
\text { one of the investigated media whereas most products with }<10 \% \text { ash did } \\
\text { not exceed adsorption rates of } 20 \% \text {. In the case of ZON, adsorption } \\
\text { efficiency ranged between } 10 \text { and } 60 \% \text {. It tended to be lowest for products } \\
\text { with MOS and beta-glucan contents }<10 \% \text { and greatest for products with } \\
\text { MOS and beta-glucan contents }>50 \% \text {. However, there was no general } \\
\text { correlation between the adsorption of ZON and the concentration of MOS }\end{array}$ \\
\hline
\end{tabular}


and beta-glucans.

Different products of one brand sold in different countries were observed to bind AFB1 to different extent which was explained by different ash contents and mineral composition. In the case of ZON, differences in adsorption between products of the same brand were less pronounced.

SCHOLARONE ${ }^{\text {'m }}$

Manuscripts 


\title{
Yeast cell based feed additives: Studies on aflatoxin $B_{1}$ and zearalenone
}

\author{
Sebastian Fruhauf ${ }^{a, \S}$, Heidi Schwartz ${ }^{a *,}$, Franz Ottner $^{\mathrm{b}}$, Rudolf Krska ${ }^{\mathrm{a}}$ and Elisavet Vekiru ${ }^{\mathrm{a}}$ \\ a. Center for Analytical Chemistry, Department for Agrobiotechnology (IFA-Tulln), University \\ of Natural Resources and Life Sciences, Vienna, Konrad Lorenz Straße 20, 3430 Tulln, \\ Austria \\ b: Institute of Applied Geology, Department of Civil Engineering and Natural Hazards, \\ University of Natural Resources and Life Sciences, Vienna, Peter Jordan Straße 70, 1190 \\ Vienna, Austria \\ $\S$ Both authors contributed equally to this work \\ ${ }^{*}$ Corresponding author \\ Email: heidi.schwartz@boku.ac.at, Tel: +43 227266280409
}

\begin{abstract}
Thirty commercially available yeast cell wall products and two reference bentonites were tested for their ability to bind aflatoxin $\mathrm{B}_{1}$ (AFB1) and zearalenone (ZON) in buffer solutions at $\mathrm{pH} 3$ and $\mathrm{pH} 6.5$ as well as in real gastric juice. For most products, the binding efficacy of AFB1 correlated with the ash content which was between 2.6 and $89 \%$ and constituted the inorganic non-volatile components, like mineral clays, of the samples. Samples with smectite as main ash component showed highest binding efficacy. Yet, correlation with the content of mannanooligosaccharides (MOS) and $\beta$-glucanes from yeast cell walls was not observed. Products containing $>30 \%$ ash showed AFB1 adsorption values $>90 \%$ at least in one of the investigated media whereas most products with $<10 \%$ ash did not exceed adsorption rates of $20 \%$. In the case of ZON, adsorption efficiency ranged between 10 and $60 \%$. It tended to be lowest for products with MOS and $\beta$-glucan contents $<10 \%$ and greatest for products with MOS and $\beta$-glucan contents $>50 \%$. However, there was no general correlation between the adsorption of ZON and the concentration of MOS and $\beta$-glucans. Different products of one
\end{abstract}


brand sold in different countries were observed to bind AFB1 to different extent which was explained by different ash contents and mineral composition. In the case of ZON, differences in adsorption between products of the same brand were less pronounced.

Keywords: Aflatoxin $\mathrm{B}_{1}$, zearalenone, adsorption, binding, yeast cell products, glucomannans, $\beta$-glucans, smectite

\section{Introduction}

Mycotoxins are an inherent problem in feed production and animal nutrition. In warm and moist countries, aflatoxins are among the main representatives. Aflatoxin $B_{1}$ (AFB1) is a potent carcinogen and can be metabolized in vivo to AFM1 which, in turn, can be found in milk and other animal products (Prandini et al. 2009). Zearalenone (ZON) is a frequently occurring mycoestrogen produced by several Fusarium species. Due to its structural similarity to estrogens like $17-\beta$-estradiol, ZON can cause reproductive problems in mammals, e.g. (Bennett et al. 2003).

Primary strategies to reduce the risk of mycotoxin contamination include good agricultural practices in the field (crop rotation, soil cultivation, weed and insect control, careful use of fungicides) and upon harvest as well as transportation and storage under dry and cool conditions (Jouany 2007). However, complete avoidance of mycotoxins is not possible. There are several approaches to cope with the problem: To lower the mycotoxin concentration in contaminated crops by physical or chemical treatment (Jouany, 2007) or to reduce the animals' mycotoxin uptake by addition of feed additives working on the basis of biological decontamination through microbes or enzymes, e.g. (Fuchs et al. 2002; Molnar et al. 2004) or on the basis of adsorption of mycotoxins to binding agents in the animals' digestive system. Binders should be non-toxic, have a high adsorption capacity (so that their inclusion level into feed may be low) and bind mycotoxins selectively and irreversibly at different $\mathrm{pH}$-values and in complex systems, like the digestive tract. Several different types of binders have been tested: Bentonites like NovaSil plus (NSP, formerly called hydrated sodium calcium aluminosilicate, HSCAS, but structurally a calcium montmorillonite clay); zeolites; organoclays; charcoal; diatomaceous earth; and yeast cell wall derived products (YCP). Unlike charcoal, NSP and other bentonites have been found to selectively bind aflatoxins through chemisorption, e.g. (Grant et al. 1998; Phillips 1995; Vekiru et al. 2007). However, the adsorptive performance (adsorption capacity, selectivity etc.) of the binders can be very different even if they belong to the same mineralogical group. Limitations of clays are that they accumulate in manure, may be contaminated with toxic metals and 
dioxins which requires rigorous testing before use and that they bind other mycotoxins than aflatoxins only to a limited extent (Yiannikouris et al. 2004a).

Glucans can be found in a wide variety of cereals, plant algae, bacteria, fungi and yeast sources (like Saccharomyces cerevisiae). Yeast glucans are major cell wall components often present as an inner wall layer and associated with other cell wall components such as chitin (together they represent about $50-60 \%$ of the wall dry weight). Strongly glycosylated mannoproteins form the outer cell wall layer. The glucan-associated activity is affected by the glucan characterizing parameters like: primary structure, solubility, degree of branching, molecular weight, as well as polymer charge and/or solution conformation (e.g. triple or single helix) (Zekovic et al. 2005). Mannanoligosaccharides (MOS) are also constituents of yeast cell walls. They are widely used in animal nutrition to enhance growth performance and gastrointestinal health. However, they have not been reported to bind mycotoxins.

Some manufacturers of yeast cell wall derived products claim that preparations containing yeast cell wall glucans, besides being nutritional aids and growth promotors, bind a variety of mycotoxins in vitro and in vivo, thereof especially ZON, without changing the nutritional value (regarding mineral and vitamin profile) of the feed. The mechanism of binding by $\beta$-Dglucans has been investigated by Yiannikouris and co-workers and has been discussed in several publications, e.g. (Yiannikouris et al. 2004a; Yiannikouris et al. 2006; Yiannikouris et al. 2004b; Yiannikouris et al. 2004c). It was shown that it is important to differentiate between the adsorption affinity of whole yeast cell wall and processed cell wall. A further factor influencing the binding ability is the presence of chitin which stiffens the cell wall structure and restricts access of e.g. ZON to the binding sites of $\beta$-D-glucans (Yiannikouris et al. 2004c). Therefore, the preparation of the cell wall material prior to its application as a mycotoxin binder is of major importance and greatly influences the adsorption ability of the final product. Hence, in order to describe the precise properties of $\beta$-D-glucan preparations, origin, molecular structure and purity are important as they are known to influence the activity of $\beta$-D-glucan preparations. It would be very useful and provide transparency for the end-user if cell wall derived products were accompanied by a certificate of analysis reporting parameters like moisture, glucan, MOS and ash content as well as other parameters like protein and fat content.

Low percentages of clays (1-6\%) are commonly added to feed as technological anti-caking feed additives. Greater percentages indicate targeted addition of clays for mycotoxin removal by binding. Possible ways to examine clay addition in products based on yeast cell 
wall ingredients are powder X-ray diffraction analysis or determination of the ash content of the product, which indicates the non-volatile inorganic matter therein.

The aim of this work was to test a great number of yeast cell wall based products for their ability to bind AFB1 and ZON and to correlate the respective adsorption rates with the glucomannan- and ash content in the samples. In addition, variations in binding efficiency within products of the same brand, but marketed in different countries and stemming from different lots, should be assessed.

\section{Materials and methods}

Reagents and solutions

Solid standards of AFB1 and ZON were provided by Romer Labs Diagnostic GmbH (Tulln, Austria). Acetonitrile (ACN, HPLC gradient grade) was purchased from VWR (Vienna, Austria) and trifluoroacetic acid (TFA) was obtained from Sigma-Aldrich (Vienna, Austria). Reagents for preparation of buffer solutions were purchased from Merck (Darmstadt, Germany) and Riedel-deHaën (Seelze, Germany). Milli-Q water prepared using an ultra-pure water system (Millipore, Molsheim, France) was used in all experiments.

Stock solutions of AFB1 (85 mg/L) and ZON (100 mg/L) were prepared in ACN. The preparation of buffer solutions (citrate buffer, $\mathrm{pH} 3.0$, and phosphate buffer, $\mathrm{pH}$ 6.5) has been described earlier (Vekiru et al. 2007). Real gastric juice (from swine) was cleaned from suspended particles by centrifugation and filtration.

\section{Tested products}

Thirty products containing different percentages of yeast cell wall constituents, mineral components and other ingredients were purchased worldwide. In addition, two mineral binders (products 1 and 2) were used as reference materials and for quality control purposes during our experimental work. Activated carbon and cholestyramine (Sigma-Aldrich and Fluka, Vienna, Austria) were chosen as positive control for binding of ZON. Product details, including manufacturers' information and our experimentally determined data like ashcontent and percentage of MOS and $\beta$-glucans are listed in Table 1, headed by the two reference bentonites and then sorted by decreasing ash content. In the case of 4 products (Mycosorb, Microbond, Integral, MTB-100), different batches - in part sold in different countries - were analyzed in order to investigate the product variations in ash, MOS and $\beta$ glucan content as well as in binding efficacy of AFB1 and ZON. 
Adsorption tests at different $\mathrm{pH}$-values and in real gastric juice

Adsorption tests were carried out at $\mathrm{pH} 3$ (citrate buffer), $\mathrm{pH} 6.5$ (phosphate buffer) and in real gastric juice from swine $(\mathrm{pH} 5): 10 \mathrm{mg}$ of adsorbent were weighed accurately $( \pm 0.3 \mathrm{mg})$ into $15 \mathrm{~mL}$ polypropylene test tubes (Sarstedt, Nuembrecht, Germany), $5 \mathrm{~mL}$ of citrate buffer, phosphate buffer or gastric juice, each containing $0.2 \mathrm{mg} / \mathrm{L}$ of AFB1 or $0.5 \mathrm{mg} / \mathrm{L}$ of ZON, were added corresponding to $0.2 \%(\mathrm{w} / \mathrm{v})$ of binder and the tubes were vortexed and incubated at $37^{\circ} \mathrm{C}$ for $1 \mathrm{~h}$ under shaking in vertical position in a rack on a microtiter plate shaker (1000/min). For each medium, $5 \mathrm{~mL}$ of a reference solution containing toxin, but no binder were treated like the samples. Immediately after incubation, the vials were centrifuged (3700 rpm, $15 \mathrm{~min}$ ) and aliquots of the buffer solutions were transferred into autosampler vials. In the case of gastric juice, $0.5 \mathrm{~mL}$ of supernatant were mixed with $0.5 \mathrm{~mL}$ of $A C N$, centrifuged to precipitate proteins and an aliquot of the clear solution was used for HPLCanalysis. As AFB1 can transform into AFB2a in acidic solutions (Vekiru et al. 2007), chromatograms were checked for AFB2a which was found to elute earlier in previous experiments. However, formation of AFB2a was not detected in any of the investigated media. Each adsorption test was carried out in triplicate for each medium, product and reference solution. Each replicate was analysed by HPLC once. The two reference bentonites were worked-up and analyzed in every experimental run for quality control purposes.

The percentage of adsorption was calculated by dividing the difference of the concentrations in the reference solution without binder (maximum concentration) and in the test solution after adsorption by the concentration in the reference solution and multiplying by 100 .

\section{Chemisorption tests}

Adsorption tests were carried out with selected products separately for AFB1 (0.2 mg/L) and ZON $(0.5 \mathrm{mg} / \mathrm{L})$ at a binder concentration of $0.5 \%(\mathrm{w} / \mathrm{v})$ and at $\mathrm{pH} 6.5$ (phosphate buffer) as described above. After shaking for $1 \mathrm{~h}$ at $37^{\circ} \mathrm{C}$ and centrifugation, the supernatant was removed for HPLC analysis and the pellet was re-suspended by vortexing in $1 \mathrm{ml}$ of buffer. The re-suspended pellet was washed twice with $1 \mathrm{~mL}$ of the buffer used for the preceding adsorption experiment and subsequently extracted 3 times with $1 \mathrm{~mL}$ each of methanol by shaking at $37^{\circ} \mathrm{C}(600 / \mathrm{min})$ for $0.5 \mathrm{~h}$. Supernatants of each washing and extraction cycle were collected and analysed separately. 
The chemisorption index $(\mathrm{C} \alpha)$ was calculated by dividing the difference of toxin adsorbed during the adsorption assay and of toxin desorbed in the course of the desorption steps by the total amount of toxin used for the adsorption assay. The percentage of desorption was determined by dividing the amount of toxin desorbed by the amount of toxin originally adsorbed and multiplication by 100 .

\section{Adsorption rate at increasing amounts of AFB1}

A constant quantity $(0.2 \% \mathrm{w} / \mathrm{v})$ of selected products (which showed high AFB1 binding efficiency in the previous test) was mixed with increasing amounts of $A F B 1$ at $37^{\circ} \mathrm{C}$ and the amount of toxin bound was evaluated. Adsorption tests were performed in gastric juice as described above using $0.2,2.0,4.0$, and $8.0 \mathrm{mg} / \mathrm{L}$ AFB1 with the exception that the samples were incubated under shaking for $24 \mathrm{~h}$ (instead of $1 \mathrm{~h}$ ).

\section{HPLC-analysis}

The HPLC system used consisted of an Agilent G1311A quaternary pump, a G1322A vacuum degasser, a G1313A autosampler, a G1316A column compartment and a G1315A UV-diode array detector. AFB1 was analyzed on a Zorbax SB Aq column (150 x $4.6 \mathrm{~mm}, 5$ $\mu \mathrm{m}$ particle size) equipped with a pre-column at $35^{\circ} \mathrm{C}$ at a flow rate of $0.7 \mathrm{~mL} / \mathrm{min}$ using $50 \%$ aqueous ACN adjusted to $\mathrm{pH} 2.9$ with TFA as mobile phase. The injection volume was 100 $\mu \mathrm{l}$ and the total run time was $7 \mathrm{~min}$. UV-absorbance was monitored at $365 \mathrm{~nm}$. Calibration was performed in the range of $10-4500 \mu \mathrm{g} / \mathrm{L}$

For HPLC analysis of ZON $25 \mu \mathrm{l}$ of sample or standard solutions were injected and separated isocratically on an Eclipse XDB-C8 column (150 x $4.6 \mathrm{~mm}, 5 \mu \mathrm{m})$ equipped with a pre-column at $25^{\circ} \mathrm{C}$ and at a flow rate of $0.8 \mathrm{~mL} / \mathrm{min}$. The mobile phase consisted of $54 \%$ aqueous methanol containing $1 \%$ of acetic acid $(\mathrm{v} / \mathrm{v})$ and the UV absorbance was recorded at $275 \mathrm{~nm}$. The total runtime was $8 \mathrm{~min}$. Calibration was carried out in the range of 10-1000 $\mu \mathrm{g} / \mathrm{L}$.

\section{Ash content}

The ash content was determined based on the AOAC Official Method 942.05. In short, $5 \mathrm{~g}$ of sample were dried over night at $105^{\circ} \mathrm{C}$ and subsequently subjected to a temperature gradient with $550^{\circ} \mathrm{C}$ as maximum- and $105^{\circ} \mathrm{C}$ as final temperature prior to cooling in a dessicator.

Mineral composition 
The mineral composition of the products was determined by powder X-ray diffraction (Moore et al. 1997). In addition, the content of carbonates was determined by Scheibler method (ÖNORM L1084) and simultaneous thermal analysis (STA, Smykatz-Kloss 1974).

\section{Content of MOS and $\beta$-glucans}

The total content of MOS and glucans was determined as described at http://www.eurasyp.org/public.technique.home.screen with minor modifications. The method involves pre-solubilization of the yeast cell wall (YCW) with concentrated sulfuric acid, subsequent acid hydrolysis, neutralization and determination of the released glucose and mannose (which are formed in proportional quantities from the glucans and mannans) by ion chromatography.

\section{Results and discussion}

\section{Products}

The ash-, MOS- and $\beta$-glucan contents and the mineral composition determined in this work are given in Table 1. Regarding the ash and MOS- plus $\beta$-glucan content of the tested products there are 3 groups to distinguish: Pure yeast or yeast cell wall products without inorganic binders added, having an ash content below $10 \%$ and generally highest percentages of MOS and glucans (41-72\%); mixtures of yeast or yeast cell wall products (30-50\%) and inorganic binding agents, containing between 10 and $30 \%$ ash; and products with ash contents $>30 \%$ composed mainly of inorganic binder with smaller percentages of yeast $(0-16 \%)$.

Ten of the investigated products contained between 3.8 and $9.8 \%$ ash. Low percentages of ash are common in yeast cell-based products because some mineral components are necessarily added during manufacturing for anti-caking purposes. Five of the products containing $<10 \%$ ash were intended for welfare of animals by offering benefits to the Gl system and by stimulating the immune system, whereas the 4 Mycosorb products were claimed to have mycotoxin binding properties. Mycotoxin binding is also the main aim of the majority of products containing $10-30 \%$ ash and $30-50 \%$ MOS and glucans. Three further products of this group were intended for well-being of animals by protecting against pathogens and by lessening the adverse effects of mycotoxins. One further product claimed to detoxify various mycotoxins by biological degradation. Finally, 7 of the 8 products ( 5 of the 6 yeast cell wall based products) containing more than $30 \%$ ash and less than $16 \%$ of MOS 
and glucans aimed at mycotoxin removal by binding and only one of these products was intended mainly to help maintain a healthy GI system.

\section{Adsorption tests at different $\mathrm{pH}$-values and in real gastric juice at $\mathrm{pH} 5$} Homogenous products with small particle size can easily be tested at small scale $(5 \mathrm{ml})$ for their binding efficacy by indirect pipetting technique, which includes preparation of a binder slurry and addition of slurry-aliquots to test tubes containing a certain concentration of the toxin. Using this technique, binder concentrations as low as $0.002 \%$ can be added reproducibly so that differentiation of high capacity binders (which all bind $100 \%$ of AFB1 at $0.2 \%$ of binder concentration) becomes possible. Yeast cell wall preparations, however, are not homogenous and product particles are rather coarse, so that indirect pipetting technique is not applicable. In order minimize the volume of toxin spiked solution required for the test we used $0.2 \%$ of the product $(10 \mathrm{mg} / 5 \mathrm{~mL}$ ) for performing the adsorption tests. This resulted in $100 \%$ binding of AFB1 by the reference bentonites, but allowed differentiation of the other products.

AFB1: The results indicated a trend that products with high ash content showed high binding efficiency of AFB1 (Figure 1A). For instance, all of the 8 products containing $>30 \%$ ash showed adsorption values $>90 \%$ at least at $\mathrm{pH} 6.5$. Likewise, 8 of the 10 products containing $<10 \%$ ash did not exceed adsorption values of $25 \%$ under any of the tested conditions ( $\mathrm{pH} 3, \mathrm{pH} 6.5$, gastric juice). Of the 14 products containing between 10 and $30 \%$ ash, five reached adsorption efficiencies of $100 \%$, 3 further products showed at least $50 \%$ adsorption in buffer solutions, 5 had adsorption rates between 30 and $50 \%$ and one was a very poor AFB1 binder, binding $<15 \%$. Hence, not only the amount, but also the type of mineral constituting the ash is a key factor in adsorption of AFB1. Therefore, the mineral composition of the individual products was determined by powder X-ray diffraction. Smectite, reported as the active ingredient in additives used as aflatoxin binders (Kannewischer et al. 2006; Marroquin-Cardona et al. 2009), was the main ingredient in 11 and a minor component in 2 further products containing $>20 \%$ ash. With the exception of the three products of the Microbond product line $(13,14,16)$, all of these products showed $>90 \%$ AFB1 adsorption in buffer and $>70 \%$ adsorption in gastric juice. Products 3 and 4 , in which smectite was not detected, showed $<50 \%$ adsorption in gastric juice. One further indication that the binding capacity of yeast cell wall derived products depends strongly on the amount and type of mineral component added is the poor binding efficacy for AFB1 of several products (e.g. products 28-32) exhibiting high MOS and $\beta$-glucan content. This observation 
is in accordance with the finding by Baptista et al. (2004) that manno-oligosaccharides and thermolysed yeast are not able to inactivate aflatoxins in vivo.

Of the 3 media tested, highest adsorption values were obtained in phosphate buffer at $\mathrm{pH}$ 6.5 , in most cases followed by citrate buffer at $\mathrm{pH} 3$. Adsorption rates in gastric juice were lowest, possibly due to adsorption of gastric juice components to the binder, reducing the binder's capacity for AFB1 (see later for further explanations).

ZON: In the case of ZON, most products showed adsorption rates between 20 and $40 \%$ (Figure 1B). Two products (No. 3, 4) were very poor binders, binding less than $15 \%$ under all of the tested conditions ( $\mathrm{pH} 3, \mathrm{pH} 6.5$, gastric juice). Only 10 products showed adsorption capabilities greater than $40 \%$ in at least one of the investigated media. Interestingly, the two reference bentonites NSP and GB7 and one further product with high ash content (No. 5, $88.9 \%$ ash) were among the best adsorbents for $\mathrm{ZON}$ at $\mathrm{pH} 3$ and 6.5 whereas 2 further products containing about $90 \%$ ash bound less than $10 \%$. This result indicates that the type and composition of mineral binder greatly affects the product's efficiency for adsorption of ZON in buffer solutions whereas the ash content itself does not seem to be a factor.

Contrary to the results in buffer solutions, adsorption in gastric juice was low $(<15 \%)$ for all products with ash contents of about $90 \%$ and MOS and $\beta$-glucan contents below $10 \%$. This suggests that these kinds of product are hardly qualified for an in vivo application. The other 7 products showing adsorption capacities greater than $40 \%$ in at least one of the investigated media also contained considerable amounts of MOS or $\beta$-glucans, which seemed to improve the ZON adsorption rates especially in real gastric juice. Moreover, several products rich in $\beta$-glucans showed greater adsorption in gastric juice than in buffer solutions.

In our study, all products containing $>10 \%$ MOS and $\beta$-glucans showed $\geq 20 \%$ adsorption in all tested media. However, although the products with greatest MOS and $\beta$-glucan content were among those with greatest adsorption, adsorption rates did not generally increase with greater MOS and $\beta$-glucan content. The type of polysaccharide (MOS or $\beta$-glucan) was not a determinant factor, either.

Activated carbon and cholestyramine, tested as positive control samples for ZON adsorption, showed adsorption rates of 100 and $74.5 \%$ at $\mathrm{pH} 3$, of 100 and $87.6 \%$ at $\mathrm{pH} 6.5$, and of 100 and $78.2 \%$ in gastric juice. 
Influence of the adsorption medium: Although the adsorption rate of AFB1 was different to that of ZON for each individual product, the ratio of adsorption of ZON to adsorption of AFB1 was similar at $\mathrm{pH} 3$ and at $\mathrm{pH} 6$ for most products. However, the ratio of adsorption of ZON to adsorption of AFB1 was greater in gastric juice than in buffer solutions for 14 products of all ash and MOS plus $\beta$-glucan contents. On the other hand, the ZON to AFB1 adsorption ratio was significantly smaller in gastric juice than in buffer solutions for the 3 products with high ash content which showed great adsorption of ZON in buffer solutions, but not in gastric juice (products 1,2 and 5). One explanation might be that gastric juice, although subjected to filtration and centrifugation prior to use, still contains components which interfere with adsorption. For instance, adsorption of ZON to gastric juice particles occurred up to $31 \%$ in the absence of binder. Hence, adsorption rates in gastric juice were corrected by the adsorption of AFB1 and ZON, respectively, in "blank" solutions of the respective toxin prepared without binder in gastric juice. Still, adsorption rates in gastric juice were increased compared to adsorption rates in buffer solutions for 14 products (see above). However, gastric juice components can also adsorb to the binder and thereby reduce its capacity for binding the target mycotoxins as observed for products 1,2 and 5 in the case of ZON. In the case of AFB1, the capacity of the reference bentonites NSP and GB7 is great enough so that this effect was not observed.

Translation of this finding into in vivo behaviour is tricky. Adsorption to gastric juice particles constitutes only a temporary mycotoxin binding as gastric juice particles are digested later in the intestinal system. Hence, the released mycotoxins should then be able to bind to mineral or MOS and $\square$-glucan components or to other indigestible diet constituents in the intestinal tract before absorption. However, due to the complexity of the involved matrices differentiation of the different adsorption processes in the Gl tract is hardly possible.

Natural variation in composition and binding efficacy between different products of one brand Frequently, products of the same brand and manufacturer, but at least in part produced in different countries are manufactured with mineral components (e.g. anti-caking agents) from local mines to avoid raw material transportation. Hence, products of the same brand but sold in different countries can differ in the type, content and composition of clay which may result in different mycotoxin adsorption efficacy. In this work, the natural variation of composition and binding efficacy of products of the same brand but of different lots and / or sold in different countries was investigated by analyzing 10 products of Mycosorb sold in 6 different 
countries; 3 products of Microbond, each sold in a different country; 2 products of Integral sold in the same country; and 2 products of MTB-100, each sold in two different countries.

in 4 different countries (CN 2, CY, IE, BR, No. 24, 25, 26, 27) was $7.3 \pm 0.7 \%$. Two further products ( $\mathrm{AU}, \mathrm{CN} 1$, No. 18, 20) were in between, containing $21.9 \pm 2.4 \%$ ash, with calcite as the main inorganic component. Likewise for AFB1: The greatest variations were observed within the Mycosorb products (Figure 2). The 4 products sold in Japan (JP 1-4, products $9,10,12,15)$ contained $27.7 \pm 1.6 \%$ ash with smectite as the main component, whereas the average ash content of 4 other products sold adsorption of AFB1 was significantly higher in the Japanese products where it amounted to $86.0 \pm 5.2 \%$ in gastric juice, $92.3 \pm 8.3 \%$ at $\mathrm{pH} 3$ and $100 \pm 0.0 \%$ at $\mathrm{pH} 6.5$. In the other 6 investigated products (of low and medium ash content, no smectite) the adsorption of AFB1 was below $30 \%$ at pH 6.5 and even below $20 \%$ at $\mathrm{pH} 3$ and in gastric juice. Similarly, the 2 products of MTB-100 sold in Vietnam and Denmark (products 21,30) differed widely in their ash contents (5.6 and $19.2 \%$ ) and in their adsorption efficacy for AFB1 (differences by a factor of $1.4-2.2$ in the individual media, see Figure 1A), even though both contained calcite as main component. In contrast to Mycosorb and MTB-100, products of Microbond sold in the USA, South Africa and Japan (products 13, 14, 16) had similar ash contents $(25.9 \pm 0.9 \%)$, similar mineral composition and showed similar adsorption under different conditions $(56.3 \pm 1.4 \%$ at $\mathrm{pH}$ $3.0,58.9 \pm 13.2 \%$ at $\mathrm{pH} 6.5,32.1 \pm 2.9 \%$ in gastric juice). The same is true for the two Integral products sold in Canada (products 11, 17, relative standard deviations (RSDs) of ash content $11.7 \%$, RSDs of adsorption under different conditions < $4.5 \%$ ).

ZON: The MOS and $\beta$-glucan contents in the 10 different products of Mycosorb varied between 32.7 and $48.6 \%$ with an average value of $41.1 \pm 5.4 \%$ (Figure $2 \mathrm{~B}$ ). The differences in adsorption of ZON between the different products were also much lower compared to the differences in adsorption of AFB1. Adsorption rates were between 24.1 and $38.4 \%$ at $\mathrm{pH} 3$, 26.6 and $38.0 \%$ at $\mathrm{pH} 6.5$ and between 25.9 and $46.0 \%$ in gastric juice. The two MTBproducts $(21,30)$ differed both in the MOS and $\beta$-glucan content (by a factor of 1.3 ) and in the adsorption of ZON in different media (by a factor of 1.07, 1.25 and 1.34 in gastric juice, at $\mathrm{pH} 6.5$ and at $\mathrm{pH} 3$, respectively). The two Integral products from Canada $(11,17)$ had similar MOS and $\square$-glucan contents, but different adsorption values (between factor 1.23 in gastric juice and factor 1.39 at $\mathrm{pH} 3$ ). On the other hand, the three Microbond products (13, $14,16)$ from different countries had a relative standard deviation (RSD) of MOS and $\beta$ glucan contents of $12.2 \%$ and RSDs of adsorption in different media between $5.9(\mathrm{pH} 3)$ and $16.6 \%$ (gastric juice). 


\section{Chemisorption tests}

In Figure 3, the chemisorption indices (Ca) of selected products are plotted together with the percentages of adsorption and desorption determined in the chemisorption experiments. In the case of AFB1, there was a strong correlation between the ash content and Ca. This is in part explained by the definition of $\mathrm{C} \alpha$ which reflects both the initial capacity of adsorption and the strength of the interactions between mycotoxin and binder. Hence, products with low adsorption under the test conditions cannot reach a $\mathrm{Ca}$ of 1 , even if no desorption takes place. In our experiments, Ca was greatest for the mineral binders and lowest for products with low ash and high MOS and $\beta$-glucan content. In addition, product 11, despite having an ash content of $28 \%$, showed adsorption of only $33 \%$ and thereof desorption of $75 \%$ which is in contrast to other products of medium ash content. In general, products with low adsorption had greatest desorption values and vice versa.

In the case of ZON, the increased ratio of product used for this test $(0.5 \% \mathrm{w} / \mathrm{v})$ resulted in significantly greater adsorption rates than the standard test using $0.2 \% \mathrm{w} / \mathrm{v}$ (see above). Yet, none of the tested products exceeded a chemisorption index of 0.2 . This is explained by high desorption of all products (65-85\% of the adsorbed amount) rather than by low adsorption values as adsorption under test conditions with $0.5 \%$ binder was between 45 and $80 \%$ for all products but one (product 3). Although products with greatest MOS and $\beta$-glucan content had greatest chemisorption indices, there was no direct correlation between $\mathrm{C} \alpha$ and the MOS plus $\beta$-glucan content. The ash content was not a factor, either. The low chemisorption indices and the high desorption values of all products indicate that ZON is adsorbed by physisorption, i.e. weak interactions with the adsorbent material and that no strong chemical bonds are formed.

\section{Adsorption rate at increasing amount of AFB1}

In this test the adsorption rate at increasing amount of the toxin was evaluated in order to compare the performance of different products which yielded similar results in the screening adsorption tests. As binder saturation during the screening test was not obtained for any of the products in the case of ZON, this test was only performed for AFB1.

On the one hand, establishment of adsorption isotherms for calculation of affinity and maximum binding capacity requires work in the range of binder saturation. On the other hand, different products should be compared under the same experimental conditions. Hence, the same percentage of binder as used in adsorption tests was chosen $(0.2 \% \mathrm{w} / \mathrm{v})$ which resulted in an almost vertical line in the isotherm plot for the reference bentonite (No. 
1) up to an initial concentration of $4 \mathrm{mg} / \mathrm{L}$ AFB1 (before addition of binder) and in significantly flatter lines for the yeast cell based products No. 7 and 10 (Figure 4). Therefore, although calculation of affinity and maximum binding capacity was not possible from the obtained data, different products with similar binding efficiency in adsorption tests could well be differentiated by means of their adsorption rates at increasing amount of AFB1.

Points to consider when comparing experimental data with other published articles

Table 2 summarizes results of published in vitro studies for the commercially available products investigated in this study. Unfortunately, for most of the products it was not possible to obtain independent experimental results (provided by someone other than the manufacturer of the product) regarding in vitro binding action. It was even more difficult to find results which refer to the product as it is sold on the market and not to formulations used for research work, which do not exactly represent the content of the commercially available product. Formulations used for research work (e.g. model compounds) are usually used in order to investigate the individual differences of various product ingredients in their mode of action and to determine factors that influence their efficacy (e.g. models of $\beta$-glucans as used by Yiannikouris et. al. (Yiannikouris et al. 2004d) or purified $\beta$-glucan fractions of yeast cell walls isolated from different strains of $S$. cerevisiae (Yiannikouris et al. 2004c)).

Further inconveniences are different experimental conditions used by the individual research groups (percentage of binder, concentration of the toxin, type and $\mathrm{pH}$ of the medium, incubation parameters), which renders comparison of the presented data difficult. One also has to distinguish between adsorption isotherms allowing the calculation of the maximum binding capacity and single adsorption studies giving just the percentage of adsorption and the amount of mycotoxin bound/kg of binder under the chosen conditions.

For instance, the amount of AFB1 bound $/ \mathrm{kg}$ of the reference binders GB7 and NSP (products 1 and 2) was $0.32 \mathrm{mmol}$ in the present work (use of $10 \mathrm{mg}$ of product, $5 \mathrm{~mL}$ of solution containing $0.2 \mathrm{mg} / \mathrm{L}$ AFB1). The same value was obtained for several other products investigated (No. 5, 7, 8, 9, 10, 12, 15, 19) in at least one of the tested media. The difference in the adsorption capacity of the products became only visible when tests at increasing amount of AFB1 were performed (see above and Figure 4). Comparison of our data obtained in single adsorption studies for the reference binders with literature values for Mycosorb and MTB-100 tested in single adsorption studies (Table 2) points out the impact of the experimental conditions on the amount of AFB1 bound $/ \mathrm{kg}$ of binder. Use of $10 \mathrm{mg}$ of binder $(0.2 \%)$ and $5 \mathrm{~mL}$ of $0.2 \mathrm{mg} / \mathrm{L}$ AFB1 solution leads to $0.32 \mathrm{mmol}$ AFB1 bound $/ \mathrm{kg}$ of 
binder for $100 \%$ adsorption whereas use of $0.1 \%$ of binder in a solution containing $0.5 \mathrm{mg} / \mathrm{L}$ AFB1 gives $1 \mathrm{mmol}$ AFB1 bound/kg of binder for an adsorption value of just $62 \%$. Hence, comparison of values obtained in single adsorption studies does not necessarily give a ranking of the best binders.

Determination of maximum adsorption capacities, which are a more useful tool for comparisons, demonstrates the superiority of mineral binders compared to yeast cell products in the adsorption of AFB1 (maximum adsorption capacities between 9 and $18 \mathrm{mmol}$ AFB1/kg binder for YCP and between 260 and $420 \mathrm{mmol} / \mathrm{kg}$ binder for mineral binders, Table 2). This efficiency of YCP may be too low for effective binding under more complex matrix conditions (as in the intestinal tract of animals).

In the case of ZON, the best performing Mycosorb products in our investigations were able to bind $0.31 \mathrm{mmol} Z O N / \mathrm{kg}$ yeast cell based product. This is in the lower range of the already reported data for single adsorption studies (see Table 2B). Again, serious comparison with literature values was hampered by different experimental conditions. Isothermal analysis has only been reported for ZON and organoclays, not for ZON and Mycosorb. The maximum adsorption capacity of organoclays is up to $390 \mathrm{mmol} Z O N / \mathrm{kg}$ binder (Lemke et al. 1998), a value which cannot be reached by YCP considering the low adsorption efficiencies at $0.2 \%$ of binder and $0.5 \mathrm{mg} / \mathrm{L} \mathrm{ZON}$ in solution (see Figure $1 \mathrm{~B}$ ).

\section{Conclusion}

This is the first study comparing the AFB1 and ZON adsorption capabilities of a great number of commercially available yeast cell products and correlating these with the ash- and MOS- as well as $\beta$-glucan contents of the products. Commercially available yeast cell based products, even of the same brand, were shown to differ in type and content of MOS and $\beta$ glucan as well as in ash content and mineral composition. Differences in the content and type of mineral clay components account for different binding capabilities of AFB1. The adsorption rate at increasing amount of the toxin (determined in order to differentiate between products with similar AFB1 binding efficiency in adsorption tests) revealed big differences between "pure" mineral binders and yeast cell based products with mineral components added.

Whereas AFB1 adsorption did not correlate with the MOS and $\beta$-glucan content of the investigated products, the ZON adsorption rate tended to increase with increasing MOS and $\beta$-glucan content. However, the adsorption capability was very low for the applied high 
inclusion rate of $0.2 \% \mathrm{w} / \mathrm{v}$ of the products and based on weak interactions. In vivo trials using mycotoxin biomarkers could be used to clarify whether the beneficial effect of yeast cell products against mycotoxicosis is based on effective binding of the toxin or on the general beneficial biological action of MOS and $\beta$-glucans to animals. In our study, ZONadsorption was independent of the type of yeast cell based product - claimed toxin binders (see Table 1) had similar or even lower binding capacities than yeast cell based additives designed for improvement of gastro intestinal health. Of the tested pure clay mineral products ( $>90 \%$ ash), some showed surprisingly great adsorption of ZON in buffer solutions (ca. $40 \%$ ), but none of them adsorbed more than $15 \%$ of ZON in gastric juice.

The impact of the product composition on the adsorption properties and the influence of experimental conditions on the amount of mycotoxin bound / $\mathrm{kg}$ of binder stresses how important it is that manufacturers present detailed product information (moisture, $\beta$-glucan and MOS as well as ash content, and also other parameters like protein, fat and content) and that authors pass on this information and add experimental details (percentage of binder used, concentration of toxin, medium and $\mathrm{pH}$ of the binding study) in their articles for better comparability of literature results. 


\section{References}

Avantaggiato G, Havenaar R, Visconti A. 2004. Evaluation of the intestinal absorption of deoxynivalenol and nivalenol by an in vitro gastrointestinal model, and the binding efficacy of activated carbon and other adsorbent materials. Food Chem Toxicol. 42: 817-824.

Avantaggiato G, Solfrizzo M, Visconti A. 2005. Recent advances on the use of adsorbent materials for detoxification of Fusarium mycotoxins. Food Addit Contam. 22: 379-388.

Baptista AS, Horii J, Calori-Domingues MA, Micotti da Gloria E, Salgado JM, Vizioli, MR. 2004. The capacity of manno-oligosaccharides, thermolysed yeast and active yeast to attenuate aflatoxicosis. World J Microbiol Biotechnol. 20: 475-481.

Bennett JW, Klich M. 2003. Mycotoxins. Clin Microbiol Rev. 16: 497-516.

Dawson KA, Evans J, Kudupoje M. 2001. Understanding the adsorption characteristics of yeast cell wall preparations associated with mycotoxin binding. In: Science and Technology in the Feed Industry. Editors: Lyons, TP, Jacques, KA, Nottingham University Press: Nottingham, U.K.: 169-181.

Diaz DE, Hagler WMJ, Hopkins BA, Whitlow LW. 2002. Aflatoxin binders I: in vitro binding assay for aflatoxin B1 by several potential sequestering agents. Mycopathologia. 156: 223-226.

Doell S, Daenicke S, Valenta H, Flachowsky G. 2004. In vitro studies on the evaluation of mycotoxin detoxifying agents for their efficacy on deoxynivalenol and zearalenone. Arch Anim Nutr. 58: 311-324.

Fuchs E, Binder EM, Heidler D, Krska R. 2002. Structural characterization of metabolites after the microbial degradation of type A trichothecenes by the bacterial strain BBSH 797. Food Add Contam. 19: 379-386.

Grant PG, Phillips TD. 1998. Isothermal adsorption of aflatoxin $\mathrm{B}_{1}$ on HSCAS Clay. J Agric Food Chem. 46: 599-605.

Jouany JP. 2007. Methods for preventing, decontaminating and minimizing the toxicity of mycotoxins in feeds. Anim Feed Sci Technol. 137: 342-362.

Kannewischer I, Tenorio Arvide MG, White N, Dixon JB. 2006. Smectite clays as adsorbents of aflatoxin $B_{1}$ : Initial steps. Clay Sci. 12, Suppl. 2: 199-204.

Lemke SL, Grant PG, Phillips TD. 1998. Adsorption of zearalenone by organophilic montmorillonite clay. J Agric Food Chem. 46: 3789-3796.

Lemke SL, Ottinger SE, Mayura K, Ake CL, Pimpukdee K, Wang N, Phillips TD. 2001. Development of a multi-tiered approach to the in vitro prescreening of clay-based enterosorbents. Anim Feed Sci Technol. 93: 17-29. 
Marroquin-Cardona A, Deng Y, Taylor JF, Hallmark CT, Johnson NM, Phillips TD. 2009. In vitro and in vivo characterization of mycotoxin-binding additives used for animal feeds in Mexico. Food Add Contam. 26: 733-743.

Molnar O, Schatzmayr G, Fuchs E, Prillinger H. 2004. Trichosporon mycotoxinivorans sp. nov., a new yeast species useful in biological detoxification of various mycotoxins. System appl microbiol. 27: 661-671.

Moore DM, Reynolds RC Jr. 1997. X-ray diffraction and the identification and analysis of clay minerals. Oxford Univ. Press, New York.

Newman K. 2000. The biochemistry behind esterified glucomannans - titrating mycotoxins out of the diet. In: Biotechnology in the Feed Industry, Proceedings of the 16th Annual Symposium. Editors: Lyons, TP, Jacques, KA, Nottingham University Press, UK.

ÖNORM L 1084: 200604 01: Chemische Bodenuntersuchungen; Bestimmung von Carbonat. Publisher: Austrian Standards Institute, Vienna.

Phillips TD. 1995. Selective chemisorption and detoxification of aflatoxins by phyllosilicate clay. Nat Tox. 3: 204-213.

Prandini A, Tansini G, Sigolo S, Filippi L, Laporta M, Piva G. 2009. On the occurrence of aflatoxin M1 in milk and dairy products. Food Chem Toxicol. 47: 984-991.

Smykatz-Kloss W. 1974. Differential Thermal Analysis, Application and Results in Mineralogy, Springer Verlag, Berlin, Heidelberg, New York.

Vekiru E, Fruhauf S, Sahin M, Ottner F, Schatzmayr G, Krska R. 2007. Investigation of various adsorbents for their ability to bind Aflatoxin B1. Mycotox Res. 23: 27-33.

Völkl A, Karlovsky P. 1999. Hefen und Tonminerale binden Mycotoxine: Wirksamkeit mineralischer und organischer Substanzen unterschiedlich. Agrarzeitung Ernährungsdienst. 24.04.

Yiannikouris A, Andre G, Buleon A, Jeminet G, Canet I, Francois J, Bertin G, Jouany JP. 2004a. Comprehensive conformational study of key interactions involved in zearalenone complexation with beta-D-glucans. Biomacromolecules. 5: 2176-2185.

Yiannikouris A, Francois J, Poughon L, Dussap CG, Bertin G, Jeminet G, Jouany JP. 2004b. Adsorption of zearalenone by beta-D-glucans in the Saccharomyces cerevisiae cell wall. J Food Prot. 67: 1195-1200.

Yiannikouris A, Francois J, Poughon L, Dussap CG, Bertin G, Jeminet G, Jouany JP. 2004c. Alkali extraction of beta-d-glucans from Saccharomyces cerevisiae cell wall and study of their adsorptive properties toward zearalenone. J Agric Food Chem. 52: 3666-3673.

Yiannikouris A, Francois J, Poughon L, Dussap CG, Jeminet G, Bertin G, Jouany JP. 2004d. Influence of $\mathrm{pH}$ on complexing of model beta-d-glucans with zearalenone. J Food Prot. 67: 2741-2746. 
Yiannikouris A, Andre G, Poughon L, Francois J, Dussap CG, Jeminet G, Bertin G, Jouany JP. 2006. Chemical and conformational study of the interactions involved in mycotoxin complexation with beta-D-glucans. Biomacromolecules. 7: 1147-1155.

Zekovic DB, Kwiatkowski S, Vrvic MM, Jakovljevic D, Moran CA. 2005. Natural and modified (1-->3)-beta-D-glucans in health promotion and disease alleviation. Crit Rev Biotechnol. 25: 205-230.

\section{Figures :}

Figure 1A, B: Adsorption efficiency, ash, beta-glucan and MOS content of 32 products for AFB1 and ZON at $\mathrm{pH} 3,6.5$ and in gastric juice

Figure 2A, B: Variability of 10 different batches of Mycosorb concerning ash content, MOS and $\square$-glucan content and adsorption in different media. Error bars denote the analytical standard deviation

Figure 3: $\mathrm{Ca}$ and percentages of adsorption and desorption of selected products

Figure 4: Adsorption rate at increasing amounts of AFB1 (products No. 1, 7 and 10). Cw: Concentration of AFB1 left in the test solution supernatant after adsorption (mg/L), q: Amount of AFB1 (g) adsorbed to $1 \mathrm{~kg}$ of product

\section{Tables:}

Table 1: Product data. Sacc. cer.: Saccharomyces cerevisiae, MT: mycotoxin, YCW: yeast cell wall, BHT: butylated hydroxytoluene

1) doughter company of Trouw Nutrition

2) manufacturer's information

${ }^{* *}$ : Main component (> 25\% of mineral content)

*: Minor component (between $\sim 1 \%$ and $25 \%$ of mineral content)

Percentage of carbonates refers to the total composition of the product

Table 2A: Overview of articles investigating adsorption of AFB1 onto yeast cell based products also included in our study

Table 2B: Overview of articles investigating adsorption of ZON onto yeast cell based products (single adsorption)

1) as stated in the original literature 
Table 1:

\begin{tabular}{|c|c|c|c|c|c|c|c|c|c|}
\hline $\begin{array}{l}\text { Product } \\
\text { No. }\end{array}$ & Product name & Provider; Marketed in & Intended use & Manufacturer's information & Mineral composition & Ash & $\beta$-Glucan & MOS & $\begin{array}{l}\beta \text {-Glucan } \\
+ \text { MOS }\end{array}$ \\
\hline 1 & Bentonite GB7 & $\begin{array}{l}\text { directly from a mine in } \\
\text { Greece; not available } \\
\text { for the end user }\end{array}$ & $\begin{array}{l}\text { anti-caking and adsorption of } \\
\text { aflatoxins }\end{array}$ & untreated bentonite & smectite $^{* \star}$, calcite $3 \%$ & 87.5 & 0.0 & 0.0 & 0.0 \\
\hline 2 & NovaSil plus & $\begin{array}{c}\text { product of Trouw } \\
\text { Nutrition Int., USA, } \\
\text { manufactured by } \\
\text { Engelhard, USA; USA }\end{array}$ & $\begin{array}{l}\text { anti-caking and adsorption of } \\
\text { aflatoxins }\end{array}$ & HSCAS & $\begin{array}{l}\text { smectite }^{* *}, \text { quartz } \\
\text { calcite } 2 \%\end{array}$ & 85.4 & 0.0 & 0.0 & 0.0 \\
\hline 3 & Select Biocycle & $\begin{array}{l}\text { Product of Select Sires, } \\
\text { USA, manufactured by } \\
\text { Agrarian Marketing } \\
\text { Corporation, USA; } \\
\text { Canada }\end{array}$ & $\begin{array}{l}\text { positive effects on gut microflora } \\
\text { and rumen microorganism }\end{array}$ & $\begin{array}{l}\text { distillers dried grains with } \\
\text { solubles, } \mathrm{CaCO}_{3} \text {, Sacc. cer. } \\
\text { active dry yeast, potassium } \\
\text { iodide, dried egg, lactic acid, } \\
\text { calcium lactate, malic acid, acetic } \\
\text { acid, tartaric acid, fumaric acid } \\
\text { and sodium benzoate }\end{array}$ & $\begin{array}{c}\text { quartz }^{*}, \text { mica }^{*} \text {, calcite } \\
1 \%\end{array}$ & 89.0 & 5.0 & 1.4 & 6.5 \\
\hline 4 & Captex FUSA & Dox-al; Bulgaria & against fusarium toxins & $\begin{array}{c}4.2-4.6 \% \text { moisture, } \\
608 \mathrm{mg} / \mathrm{kg} \text { clinoptilolite, } \\
116 \mathrm{mg} / \mathrm{kg} \text { Resindox }{ }^{\mathrm{TM}}, \\
207 \mathrm{mg} / \mathrm{kg} \text { esterified } \\
\text { glucomannans (Sacc. cer.) and } \\
185 \mathrm{mg} / \mathrm{kg} \mathrm{CaCO}{ }_{3}\end{array}$ & $\begin{array}{l}\text { dolomite }^{\star *} \text {, zeolite } \\
\text { feldspars } \\
1 \% \text {, calcite } \\
1 \% \text { dolomite } 60 \%\end{array}$ & 89.0 & 5.2 & 3.4 & 8.6 \\
\hline 5 & Finale & Marsyt, USA; USA & MT removal by adsorption & $\begin{array}{l}\text { montmorillonite clay, } \\
\text { diatomaceous earth, } \\
\text { Sacc. cer., magnesium silicate, } \\
\text { calcium propionate }\end{array}$ & $\begin{array}{c}\text { quartz } \\
\text { smectite }^{*}, \text { calcite } 3 \%\end{array}$ & 88.9 & 2.8 & 1.4 & 4.2 \\
\hline 6 & MT.X Plus ${ }^{\circledR}$ & Olmix, France; UK & MT removal by adsorption & $\begin{array}{l}\text { amadéite, montmorillonite, } \\
\text { diatomaceous earth, yeast cell } \\
\text { walls }\end{array}$ & $\begin{array}{l}\text { quartz*, mica*, calcite } \\
13 \% \text {, dolomite } 2 \%\end{array}$ & 75.0 & 5.9 & 4.3 & 10.2 \\
\hline 7 & Mastersorb Gold ${ }^{\circledast}$ & Grasp, Brasil; Brasil & $\begin{array}{l}\text { MT (fumonisins, ZON, T2, DON, } \\
\text { AFB1) removal by adsorption, } \\
\text { protection against pathogens }\end{array}$ & $\begin{array}{c}\text { mineral, phycolytic and } \\
\text { phytogenic components, details } \\
\text { unknown }\end{array}$ & $\begin{array}{l}\text { quartz }^{*}, \text { smectite }^{*}, \\
\text { kaolinite }^{*}, \text { mica*}^{*} \\
\text { calcite } 2 \%\end{array}$ & 65.2 & 10.0 & 5.9 & 15.8 \\
\hline 8 & Tonilys & $\begin{array}{c}\text { Nordos, France }{ }^{1)} \\
\text { France }\end{array}$ & $\begin{array}{l}\text { MT removal (AFB1, ZON, DON) } \\
\text { by adsorption, stimulation of } \\
\text { liver function, immune } \\
\text { stimulation due to MOS and }\end{array}$ & $\begin{array}{l}\text { mineral clay (sodium bentonite), } \\
\text { dried yeast extract, antioxidants } \\
\text { (BHT) }\end{array}$ & $\begin{array}{l}\text { smectite }^{* \star} \text {, quartz*, } \\
\text { gibbsite }^{*} \text {, calcite } 3 \%\end{array}$ & 59.1 & 8.5 & 6.1 & 14.6 \\
\hline
\end{tabular}


vitamin E, anti-oxidative effect

Microbond_USA

Cenzone, USA; USA

Mycosorb_Japan_1

Alltech, USA; Japan

$$
\begin{aligned}
& \text { Africa } \\
& \text { a }
\end{aligned}
$$

Alltech, USA; Japan

Mycosorb_Japan_4

Microbond_Japan

Cenzone, USA; Japan
MT removal by adsorption

see product No. 9

MT removal by adsorption

see product No. 9

immunostimulation, protection against pathogens, improvement of digestion and nutrient adsorption, diminishing of adverse effects of MTs

see product No. 13

see product №. 13

see product No. 11

Sacc. cer. extract $>60 \%$,
HSCAS, $\mathrm{CaCO}_{3}$
see product No. 9

yeast by-product

see product No. 9

$\beta$-glucans, MOS, digestive enzymes

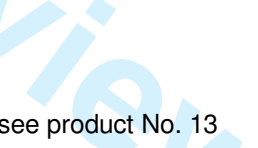

ee product No. 9

ee product No. 13 smectite $^{\star *}$, quartz ${ }^{*}$, feldspars*, calcite $3 \%$, dolomite $2 \%$

$\begin{array}{lll}29.7 & 19.7 & 13.0\end{array}$

smectite $^{* \star}$, quartz calcite $3 \%$, dolomite

$$
1 \%
$$

calcite $17 \%$, dolomite

$$
7 \%
$$

smectite $^{* *}$, quartz ${ }^{*}$,

calcite $2 \%$, dolomite$$
1 \%
$$

smectite $^{* *}$, quartz ${ }^{*}$

sodium sulfate*,

aluminium sulfate hydrate ${ }^{*}$, calcite

smectite $^{* *}$, quartz sodium sulfate*, aluminium sulfate hydrate ${ }^{*}$, calcite $\sim 0.5 \%$

smectite $^{* *}$, quartz ${ }^{*}$, calcite $2 \%$, dolomite

$\sim 0.5 \%$

smectite $^{\star *}$, quartz ${ }^{*}$, sodium sulfate ${ }^{*}$, aluminium sulfate hydrate ${ }^{*}$, calcite $\sim 0.5 \%$

calcite $15 \%$, dolomite $7 \%$ 

removal by adsorption

\section{MT (AFB1, ZON, T2-toxin)} removal by adsorption hydrolysis, extraction and hydrolysis, extraction and
further treatment)

\section{U.S. Patent No 6045834, MT}

\section{see product No. 9}
max. $8 \%$ moisture, $17-25 \%$ ash, $>45 \%$ carbohydrates ( $\beta$-glucans + MOS
$20+5$ proteins \pm 5 proteins
$5-12 \%$ fat

see product No. 9

molasses distillers dried solubles, maize condensad distillers maize condensad distillers
solubles, $\mathrm{HSCAS}, \mathrm{CaCO}_{3}$ solubles,
min. crude protein $22 \%$, min. crude protein $22 \%$,
max. crude fat $0.5 \%$, max. crude fiber $11 \%$, max.

$$
\text { moisture } 15 \%
$$

min. crude protein $32 \%$, max. fiber $1 \%$,
max. moisture $8 \%$,

biological degradation of ZON FB1, OTA, T2 by Sacc. telluris of aflatoxins

max. ash $18 \%$, min. $\beta$-glucans $14 \%$

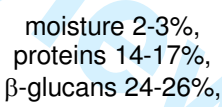

see product No. 9
$6 \%$

smectite $^{\star *}$, quartz ${ }^{*}$, feldspars*, cristobalite*

22

calcite $13 \%$, dolomite

$$
6 \%
$$

calcite $12 \%$, dolomite

$$
5 \%
$$

$$
19.2
$$

quartz $^{*}$, zeolite*

$$
\text { K-feldspar* }
$$

calcite $\sim 0.5 \%$

$$
9.8
$$

quartz*, zeolite*

not determined

quartz*, zeolite*, calcite $1 \%$ 
protection against pathogens,

positive effects on gut microflora

(prebiotic

rom cell wall of Sacc. cer)

humoral immune response,

positive effects on animal

growth; action based on cell wall of Sacc. cer.

MTB-100_Denmark Alltech, USA; Denmark

see product No. 21

protection against pathogens, benefits for the Gl system

removal of MTs and pathogenic

bacteria by adsorption,

timulation of immune system

and prebiotic properties (contains extracted Sacc. cer.) max. protein $30 \%$, max. moisture $8 \%$ MOS $25 \pm 3 \%$,

$\beta$-glucans $30 \pm 3 \%$,

$$
\text { ash } 6 \%
$$

min. $\beta$-glucan $70 \%$, max. moisture $10 \%$ ash $5.7 \%$

not determined
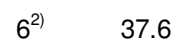

19.9

not determined

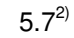

67.0

see product No. 21

calcite $4 \%$

5.6

36.9

18.6

details unknown

not determined

crude protein $25 \%$, crude fat $7.5 \%$, $\beta$-glucan $35-30 \%$ MOS $20-25 \%$

undefined mineral traces 3.8 
Table 2A: Overview of articles investigating adsorption of AFB1 onto YCP also included in our study.

\begin{tabular}{|c|c|c|c|c|c|c|c|}
\hline \multicolumn{8}{|c|}{ AFB1-Adsorption } \\
\hline $\begin{array}{l}\text { Product } \\
\text { name }\end{array}$ & $\begin{array}{c}\text { Percentage } \\
\text { of binder } \\
\text { used }(\%)\end{array}$ & solvent & $\mathrm{pH}$ & $\begin{array}{l}\text { Toxin } \\
\text { conc } \\
{[\mathrm{mg} / \mathrm{L}]}\end{array}$ & $\begin{array}{l}\text { Type of } \\
\text { study }\end{array}$ & $\begin{array}{c}\text { mmol AFB1 } \\
\text { bound/kg } \\
\text { binder }\end{array}$ & Literature \\
\hline $\begin{array}{l}\text { Bentonite } \\
\text { GB7 }\end{array}$ & $0.002 \%(w / v)$ & buffer & 7.0 & $0.4-8$ & $\begin{array}{l}\text { adsorption } \\
\text { isotherm }\end{array}$ & Max 420 & $\begin{array}{l}\text { (Vekiru et al. } \\
2007 \text { ) }\end{array}$ \\
\hline $\begin{array}{l}\text { NovaSil } \\
\text { plus }\end{array}$ & $\begin{array}{l}0.02 \mathrm{mg} / \mathrm{mL} \stackrel{\wedge}{=} \\
0.002 \%(\mathrm{w} / \mathrm{v})\end{array}$ & buffer & $2.0 \& 6.5$ & $0.4-8$ & $\begin{array}{l}\text { adsorption } \\
\text { isotherm }\end{array}$ & Max 396 & $\begin{array}{l}\text { (Marroquin- } \\
\text { Cardona et al. } \\
\text { 2009) }\end{array}$ \\
\hline $\begin{array}{l}\text { NovaSil } \\
\text { plus }\end{array}$ & $0.002 \%(w / v)$ & buffer & 7.0 & $0.4-8$ & $\begin{array}{l}\text { adsorption } \\
\text { isotherm }\end{array}$ & Max 390 & $\begin{array}{l}\text { (Vekiru et al. } \\
\text { 2007) }\end{array}$ \\
\hline HSCAS & $0.002 \%(w / v)$ & water & unadjusted & $0.4-8$ & $\begin{array}{l}\text { adsorption } \\
\text { isotherm }\end{array}$ & Max 260 & $\begin{array}{l}\text { (Lemke et al. } \\
\text { 2001) }\end{array}$ \\
\hline $\begin{array}{l}\text { HSCAS } \\
\text { (NovaSil) }\end{array}$ & $0.001 \%(w / v)$ & water & unadjusted & $0.4-8$ & $\begin{array}{l}\text { adsorption } \\
\text { isotherm }\end{array}$ & Max 336 & $\begin{array}{c}\text { (Grant et al. } \\
\text { 1998) }\end{array}$ \\
\hline Mycosorb & $\begin{array}{l}0.02 \mathrm{mg} / \mathrm{mL} \triangleq \\
0.002 \%(\mathrm{w} / \mathrm{v})\end{array}$ & water & $2.0 \& 6.5$ & $0.4-8$ & $\begin{array}{l}\text { adsorption } \\
\text { isotherm }\end{array}$ & $\operatorname{Max} 9 \& 15$ & $\begin{array}{l}\text { (Marroquin- } \\
\text { Cardona et al. } \\
\text { 2009) }\end{array}$ \\
\hline Mycosorb & $\begin{array}{l}1 \mathrm{mg} / \mathrm{mL} \stackrel{\wedge}{=} \\
0.1 \%(\mathrm{w} / \mathrm{v})\end{array}$ & $\begin{array}{l}\text { aqueous } \\
\text { solution }\end{array}$ & not given & $2-10$ & $\begin{array}{l}\text { adsorption } \\
\text { isotherm }\end{array}$ & $\operatorname{Max} 17.6$ & $\begin{array}{l}\text { (Dawson et al. } \\
\text { 2001) }\end{array}$ \\
\hline Mycosorb & $0.1 \%(w / v)$ & unknown & not given & 0.5 & $\begin{array}{c}\text { single } \\
\text { adsorption } \\
(62 \% \\
\text { adsorption) }\end{array}$ & 1 & (Newman 2000) \\
\hline MTB-100 & $1 \%(w / v)$ & $\begin{array}{c}\text { water/MeOH } \\
(9: 1)\end{array}$ & $\begin{array}{l}3,7,10 \text { and } \\
\text { unadjusted }\end{array}$ & 5.0 & $\begin{array}{c}\text { SIngle } \\
\text { adsorption } \\
(97 \% \\
\text { adsorption) } \\
\end{array}$ & 1.55 & (Diaz et al. 2002) \\
\hline
\end{tabular}

Table 2B: Overview of articles investigating adsorption of ZON onto YCP also included in our study. (single adsorption)

\begin{tabular}{|c|c|c|c|c|c|c|c|}
\hline \multirow[b]{2}{*}{$\begin{array}{l}\text { Product } \\
\text { name }\end{array}$} & \multicolumn{7}{|c|}{ ZON-Adsorption } \\
\hline & $\begin{array}{l}\text { Percentage } \\
\text { of binder } \\
\text { used (\%) }\end{array}$ & Solvent & $\mathrm{pH}$ & $\begin{array}{c}\text { Toxin } \\
\text { conc } \\
{[\mathrm{mg} / \mathrm{L}]}\end{array}$ & $\begin{array}{c}\% \\
\text { adsorption }\end{array}$ & $\begin{array}{c}\mathrm{mmol} \text { AFB1 } \\
\text { bound/kg } \\
\text { binder }\end{array}$ & Literature \\
\hline Mycosorb & $\begin{array}{l}1 \mathrm{mg} / \mathrm{mL} \wedge \\
0.1 \%(\mathrm{w} / \mathrm{v})\end{array}$ & buffer & $3.0 \& 8.0$ & 2 & $38 \& 42$ & $\begin{array}{c}2.4 \& \\
2.6\end{array}$ & $\begin{array}{l}\text { (Avantaggiato } \\
\text { et al. 2005) }\end{array}$ \\
\hline Mycosorb & $\begin{array}{l}1 \mathrm{mg} / \mathrm{mL} \triangleq \\
0.1 \%(\mathrm{w} / \mathrm{v})\end{array}$ & buffer & $3.0 \& 8.0$ & 20 & $23 \& 18$ & $1.4 \& 1.1$ & $\begin{array}{l}\text { (Avantaggiato } \\
\text { et al. 2005) }\end{array}$ \\
\hline $\begin{array}{l}\text { Mycosorb } \\
\text { Extra }\end{array}$ & $\begin{array}{c}10.2 \mathrm{mg} / \mathrm{mL} \stackrel{\wedge}{=} \\
1.02 \%(\mathrm{w} / \mathrm{v})\end{array}$ & buffer & $\begin{array}{l}\text { changed } \\
\text { during } \\
\text { incubation } \\
\text { from 3-7 }\end{array}$ & 0.334 & 88.7 & 0.09 & $\begin{array}{l}\text { (Doell et al. } \\
\text { 2004) }\end{array}$ \\
\hline Mycosorb & $\begin{array}{c}1 \mathrm{mg} / \mathrm{g} \stackrel{\wedge}{=} \\
0.1 \%(\mathrm{w} / \mathrm{w})^{1)}\end{array}$ & not given & unknown & $0.25-2$ & $22-40$ & $<2.5$ & $\begin{array}{l}\text { (Newman } \\
2000)\end{array}$ \\
\hline
\end{tabular}


1

2

3

4

5

6

7

8

9

10

11

12

13

14

15

16

17

18

19

20

21

22

23

24

25

26

27

28

29

30

31

32

33

34

35

36

37

38

39

40

41

42

43

44

45

46

47

48

49

50

51

52

53

54

55

56

57

58

59

60

\begin{tabular}{llllllll}
\hline Mycosorb & $1 \%(\mathrm{w} / \mathrm{v})$ & buffer & 4.5 & 40 & 68 & 8.5 & $\begin{array}{c}\text { (Völkl et al. } \\
\text { 1999) }\end{array}$ \\
\hline
\end{tabular}

http://mc.manuscriptcentral.com/tfac Email: fac@tandf.co.uk 
Figure 1A:

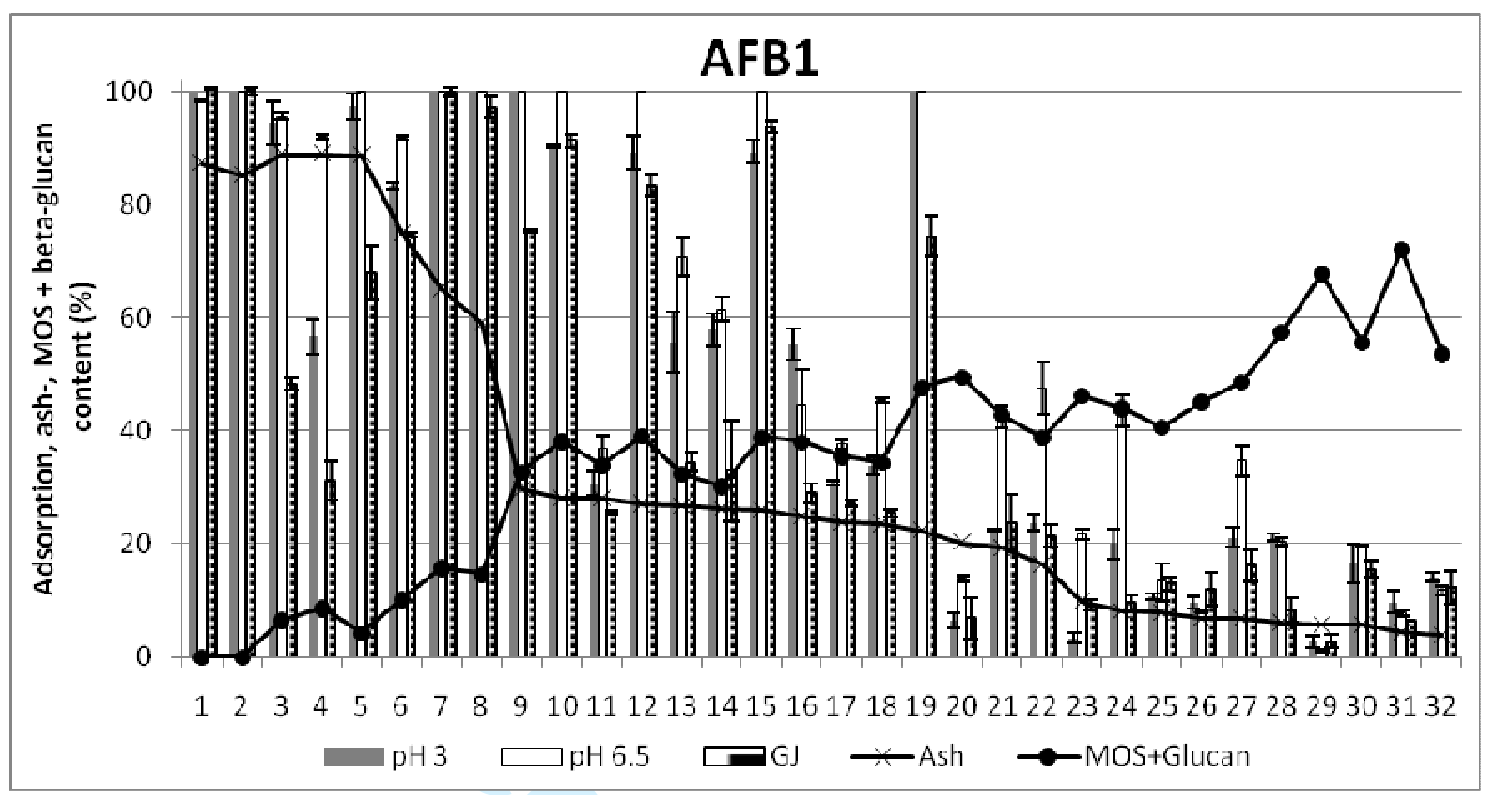

Figure 1B:

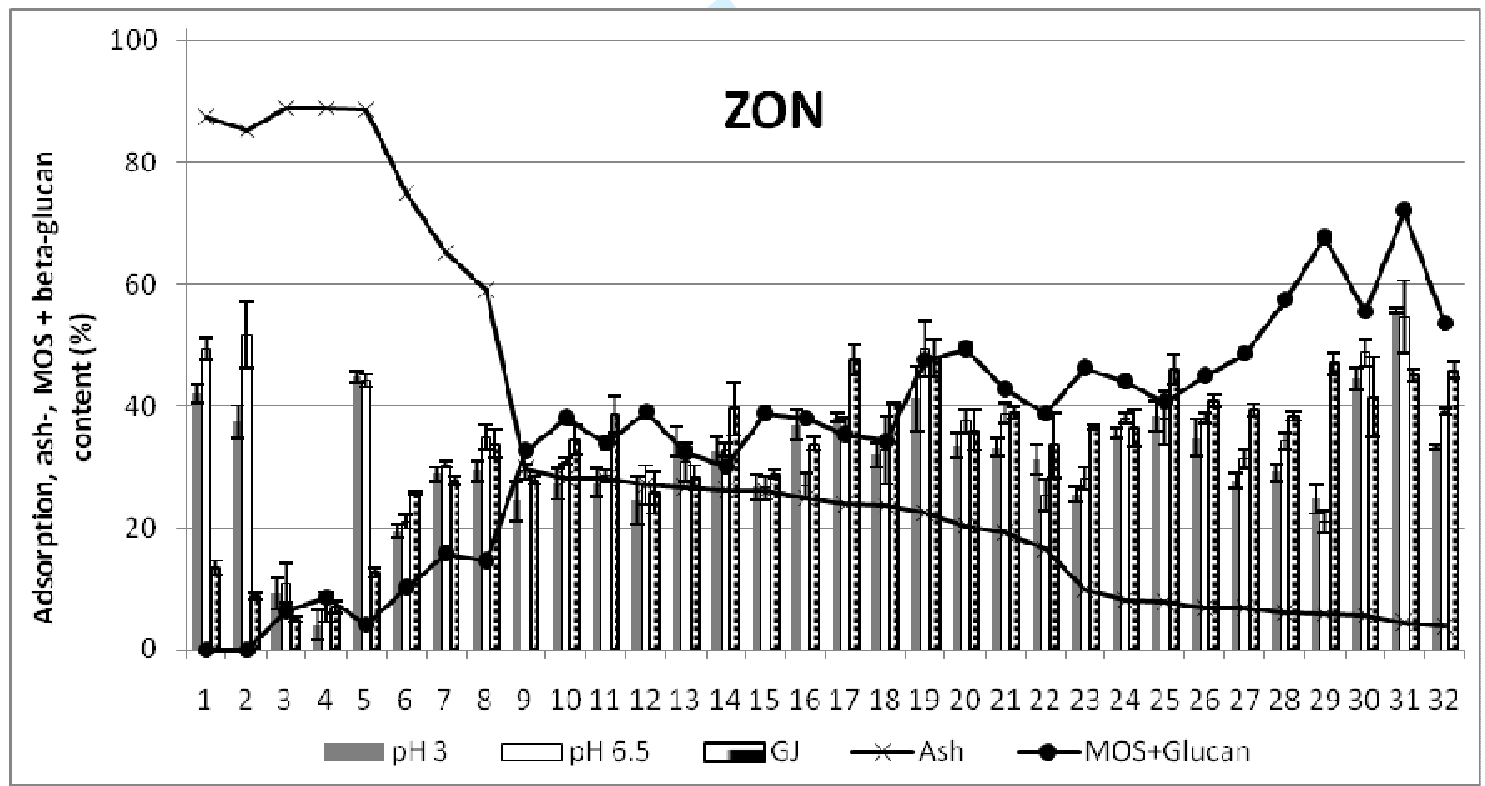

http://mc.manuscriptcentral.com/tfac Email: fac@tandf.co.uk 
Figure 2A:

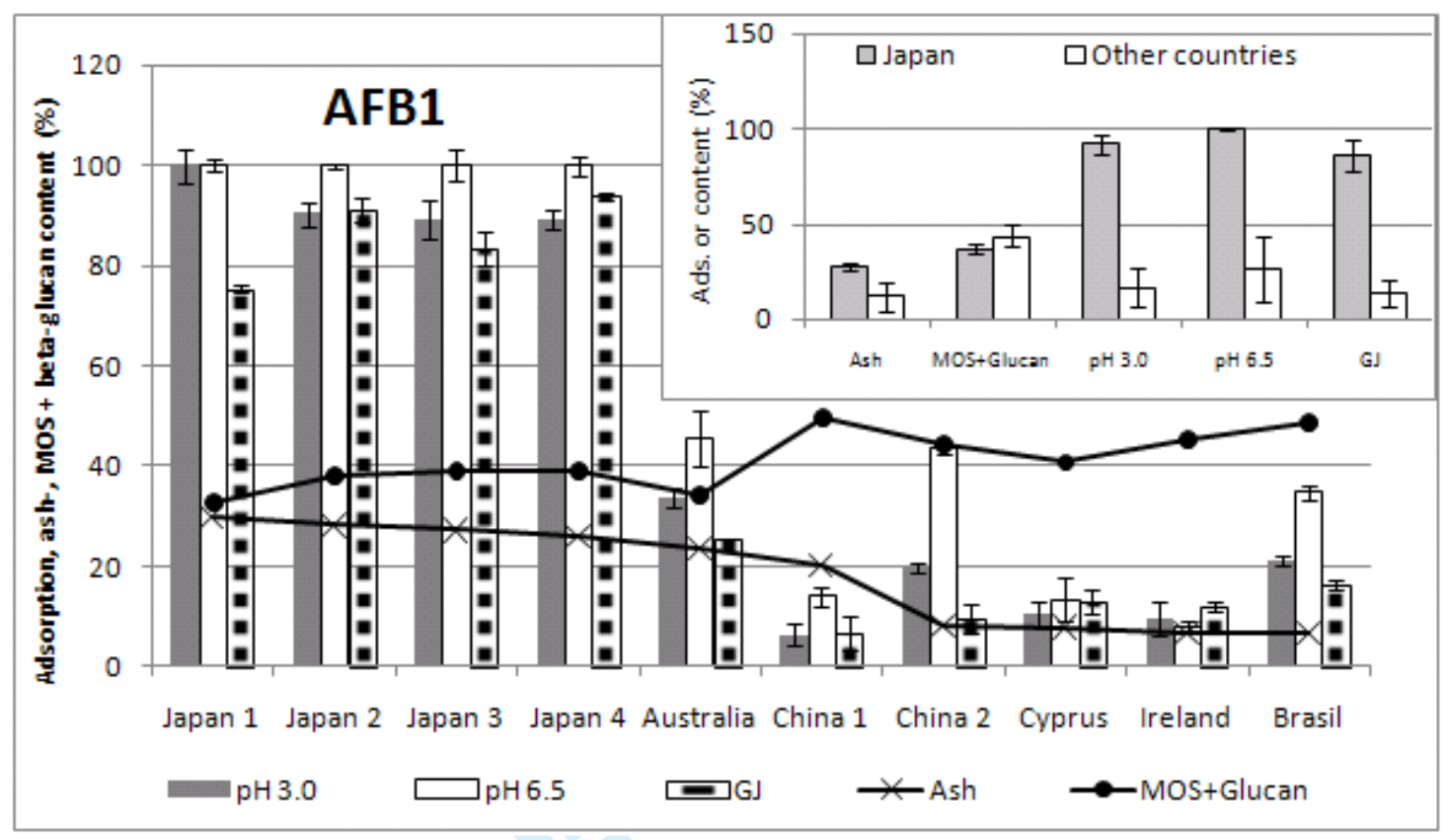

Figure 2B:

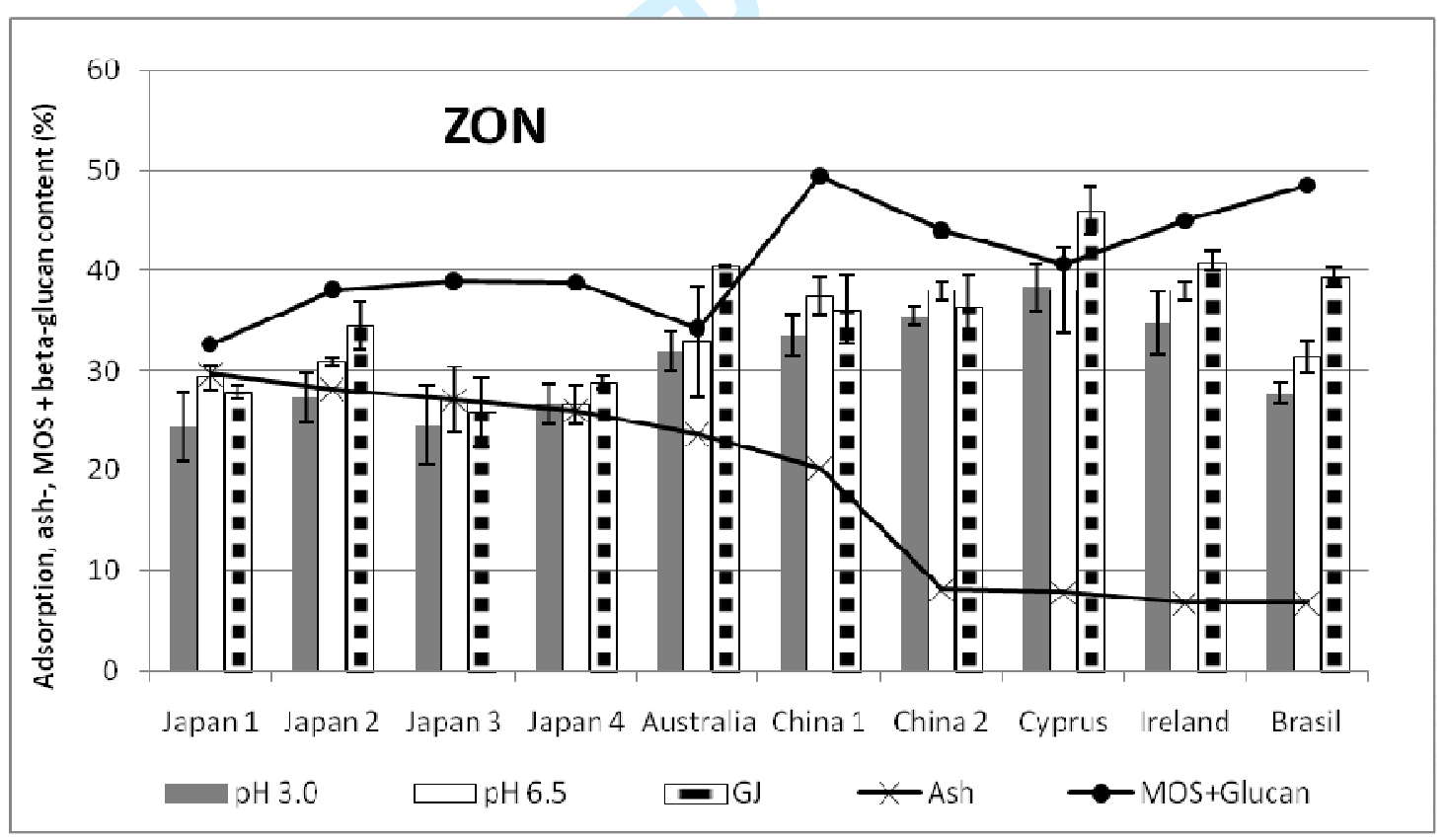

http://mc.manuscriptcentral.com/tfac Email: fac@tandf.co.uk 
Figure 3:

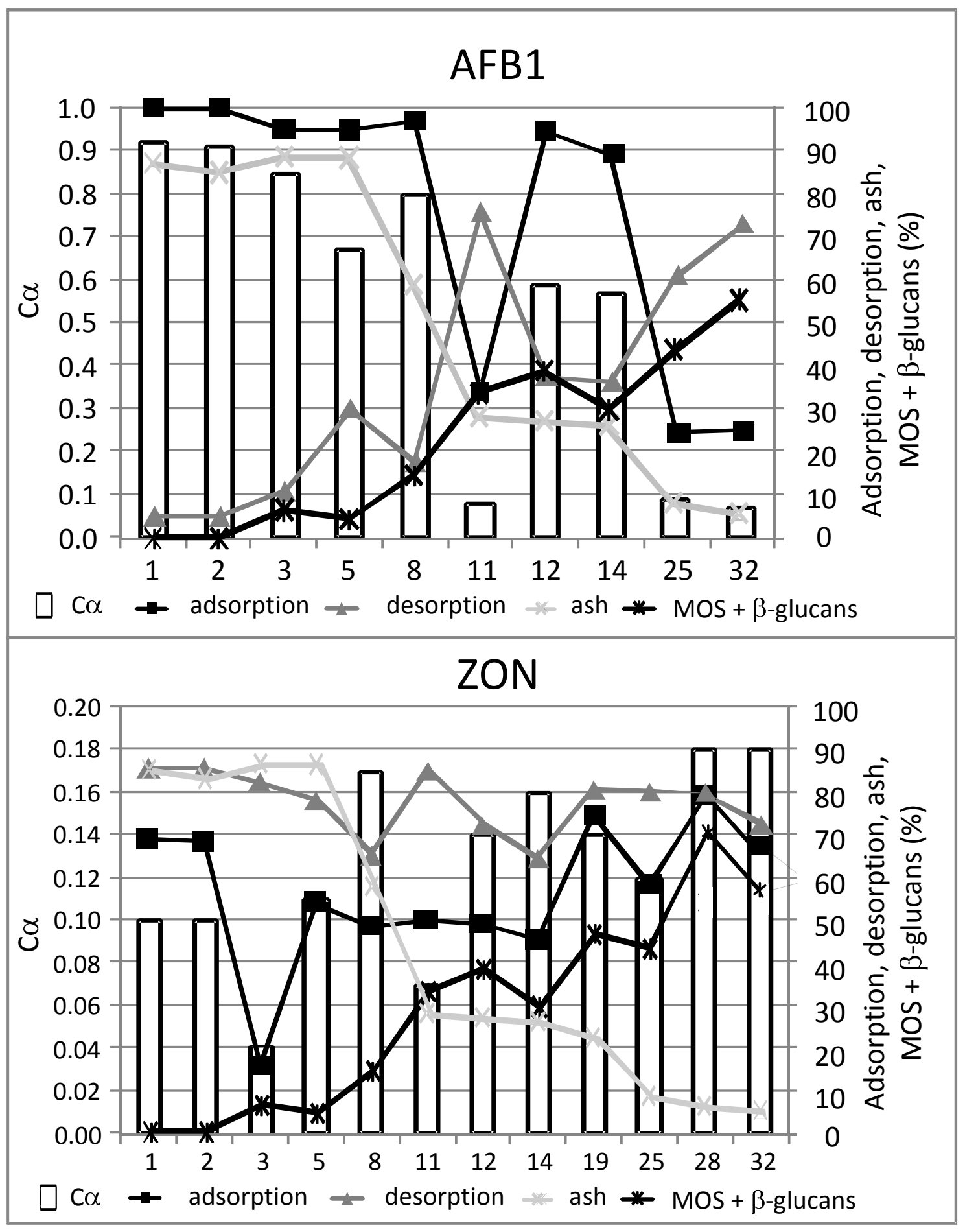

http://mc.manuscriptcentral.com/tfac Email: fac@tandf.co.uk 
Figure 4:

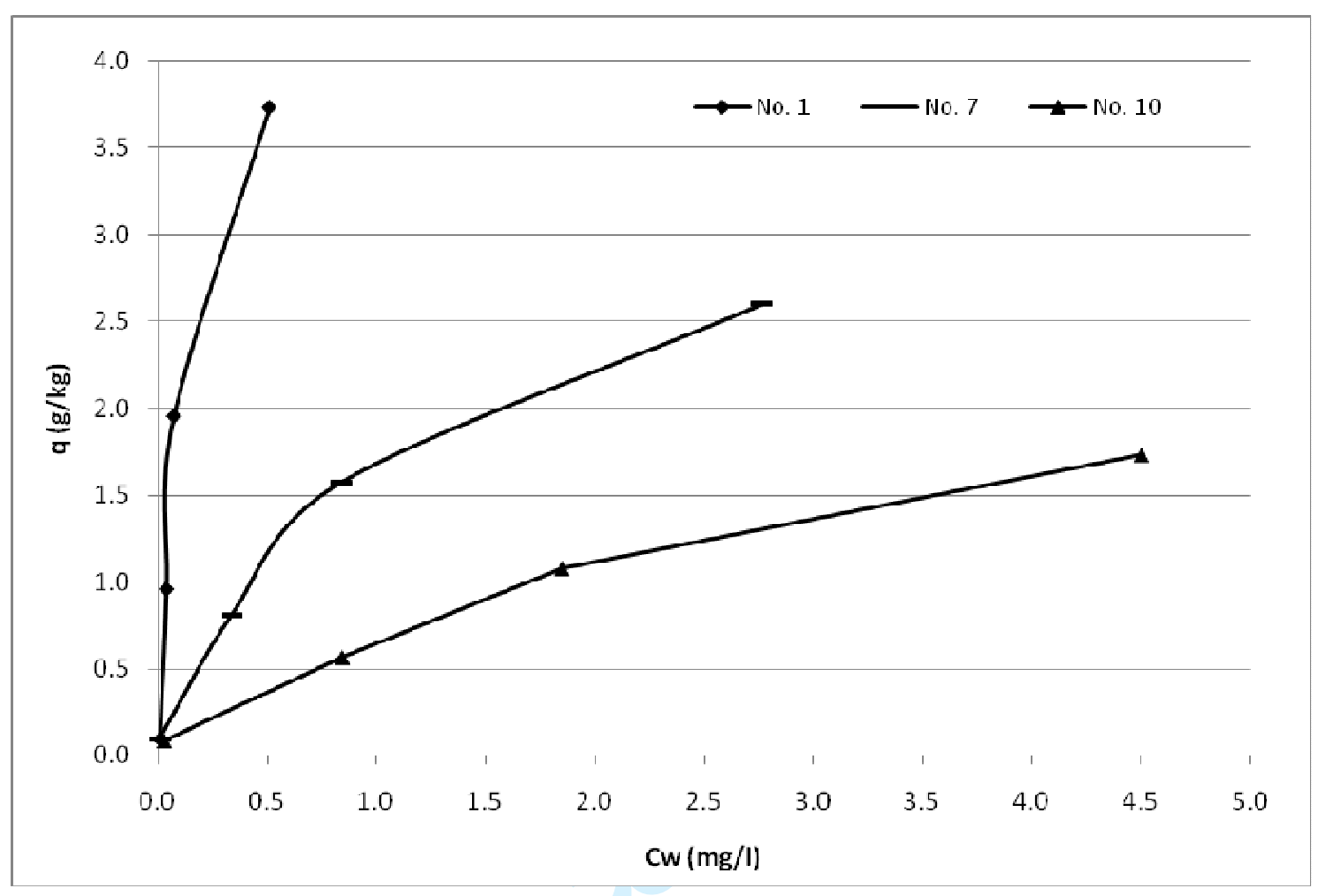

29

33

34

35

36

37

38

39

40

41

42

43

44

45

46

47

48

49

50

51

52

53

54

55

56

57

58

59

60

http://mc.manuscriptcentral.com/tfac Email: fac@tandf.co.uk 